Annals of Plant and Soil Research 23(3): 324-328 (2021)

https://doi.org/10.47815/apsr.2021.10078

\title{
Chlorophyll content and spad value of rice (Oryza sativa I.) under different sowing windows and nutrient management practices
}

\author{
B.P. PATRA ${ }^{1}$, S.N. JENA ${ }^{2}$, M.R. SATAPATHY ${ }^{3}$, R.K. PANDA ${ }^{4}$, S.D. BEHERA ${ }^{5}$ AND S.G. SAHU ${ }^{6}$
}

Department of Agronomy, Odisha University of Agriculture and Technology, Bhubaneswar, Odisha

Received: April, 2021: Revised accepted: June, 2021

\begin{abstract}
The field experiment was conducted during kharif seasons of 2018 and 2019 in Agronomy research farm ,OUAT on rice using two dates of planting $\left(10^{\text {th }}\right.$ july, $25^{\text {th }}$ july) in main plot and three nutrient management practices (STBFR (Soil test based fertilizer recommendation), STBFR+GM, STBFR+FYM) in sub plot in a split plot design with four replications. Chlorophyll content as well as SPAD values of the crop measured at different growth stages of rice at 30 days interval revealed that chlorophyll a, chlorophyll b, total chlorophyll as well as SPAD values of the crop increased till 60 DAP and thereafter decreased. Early planting recorded higher chlorophyll a value of $2.36 \mathrm{mg} \mathrm{g}^{-1}$ of fresh leaf, chlorophyll $b$ value of $1.26 \mathrm{mg} \mathrm{g}^{-1}$, total chlorophyll value of 3.62 $\mathrm{mg} \mathrm{g}^{-1}$ and SPAD value of 44.73, while STBFR + GM treatment registered higher Chlorophyll a value of 2.55 $\mathrm{mg} \mathrm{g}^{-1}$, Chlorophyll b value of $1.38 \mathrm{mg} \mathrm{g}^{-1}$, total chlorophyll value of $3.99 \mathrm{mg} \mathrm{g}^{-1}$ and SPAD value of 46.87 . Leaf $N$ content as well as grain yield is also found higher in early planting $\left(2.58 \%, 5008 \mathrm{~kg} \mathrm{ha}^{-1}\right)$ and STBFR + GM $\left(2.74 \%, 5015 \mathrm{~kg} \mathrm{ha}^{-1}\right)$. Significant positive linear relationship was observed between leaf N content and SPAD value of the crop which ultimately influences grain yield of the crop.
\end{abstract}

Key words: Chlorophyll, SPAD value, planting time, nutrient management practices, rice

\section{INTRODUCTION}

Nitrogen and its management play a significant role in achieving yield in low land rice ecosystem. It is also a prime nutrient for protein and carbohydrate synthesis, growth and development of plant. The effect of nitrogen on rice growth and grain productivity are derived from several biochemical, physiological and morphological processes in the plant system. It is, however, one of the most expensive inputs and if used improperly, can pollute the ground water. Farmers often apply larger quantities of fertilizers than strictly required for achieving maximum yield, to ensure potential yield every year. However, excessive use of fertilizer causes lodging, disease and results in increased input costs and net yield reduction. Also Fertilizer $\mathrm{N}$ use efficiency of rice is relatively low due to rapid losses of applied $\mathrm{N}$ through volatilization and denitrification. Traditionally, the optimum rate of Nutrient -fertilization has been the rate that results in maximum economic yield, but that also sometime not optimum for plant or excess than required. For which an attempt to reduce the loss, application of proper amount and improve its uptake by the plant through combining the addition of chemical fertilizer (STBFR) with GM \& FYM is essential.

Monitoring the nitrogen status of crop involving plant based strategies is another approach for improving nitrogen use efficiency. The correlation between leaf area and yield suggests that chlorophyll and leaf area are important in determining the yield. The chlorophyll content in leaf tissues varies with the age of the plant, the species and the growing season. Comparison of crop growth patterns and time of sowing, source of nutrient application indicates that improved congruence of $\mathrm{N}$ supply and crop demand was the primary reason for increased fertilizer use efficiency and high yields with SPAD based nutrient management system. With the help of Chlorophyll content as well as chlorophyll meter reading we can also find out the nutrient use efficiency at different stages. Hence the chlorophyll content of rice plants was studied over a period of 13 weeks coinciding with different stages, and its relation with leaf $\mathrm{N}$ content and grain yield was determined with SPAD meter as diagnostic tools for predicting grain yield response to nutrient management and date of planting.

Email: bishnupriya11patra@gmail.com, ${ }^{7}$ PhD. Student (Agronomy), ${ }^{2}$ Professor (Agronomy), ${ }^{3}$ Professor (Agronomy), ${ }^{4}$ Professor (Plant Physiology), ${ }^{5} \mathrm{PhD}$. Student (Agronomy), ${ }^{6} \mathrm{PhD}$. student (Soil Science), OUAT, Bhubaneswar (Odisha)-751003 


\section{MATERIALS \& METHODS}

A field experiment was conducted at Agronomy research farm, OUAT $\left(20^{\circ} 15 " \mathrm{~N}\right.$ Latitude and $85^{\circ} 52^{\prime \prime}$ E Longitude) during Kharif seasons of 2018 and 2019 to study the response of rice variety Naveen to two dates of planting $\left(10^{\text {th }}\right.$ july, $25^{\text {th }}$ july) and three nutrient management practices (STBFR, STBFR+GM (25 kg/ha), STBFR+FYM (4 ton/ha)) in a split plot design with four replications. The crop was grown by adopting standard agronomic practices. The chlorophyll content was measured by taking fresh leaf tissue $(10 \mathrm{mg})$ and was cut into small pieces and incubated in $10 \mathrm{ml}$ of $80 \%$ Ethanol in dark for $24 \mathrm{hr}$ covering completely. After the incubation period, the sample was taken for optical measurement. The optical density was measured at 645,663 and $480 \mathrm{~nm}$ in UV-VIS Spectrophotometer. Care was taken to make the final volume to $10 \mathrm{ml}$ with $80 \%$ ethanol, wherever the volume was reduced during incubation. Chlorophyll-a, chlorophyll-b and total chlorophyll contents were calculated using the formulae given by Nayek et. al, (2014). SPAD value was measured with the help of
SPAD meter/Chlorophyll meter from the third leaf of the plant during morning hours. The experimental data generated on different biochemical parameters over the years were subjected to pooled analysis following the procedures mentioned in Gomez and Gomez (1984).

\section{RESULTS AND DISCUSSION}

Chlorophyll a, b and total chlorophyll content $(\mathrm{mg} / \mathrm{g})$ estimated at different stages of rice were influenced by dates of planting and nutrient management. Chlorophyll content increased initially and higher chlorophyll content was observed at 60 DAP $\left(2.36 \mathrm{mg} \mathrm{g}^{-1}\right)$ followed by a decrease in chlorophyll content. Chlorophyll content did not differ significantly from each other by date of planting but early planting had numerically higher chlorophyll a $(2.29,2.36,1.20$ $\left.\mathrm{mg} \mathrm{g}^{-1}\right)$, Chlorophyll b $\left(1.02,1.26,0.69 \mathrm{mg} \mathrm{g}^{-1}\right)$ and total chlorophyll $\left(3.02,3.67,1.89 \mathrm{mg} \mathrm{g}^{-1}\right)$ than late planting method. There was $2.96,4.76$, $3.87 \%$ increase in Chlorophyll a, chlorophyll b, total chlorophyll content of rice over late planting at 60 DAP (Table 1.), respectively.

Table 1: Chlorophyll content ( $\mathrm{mg} \mathrm{g}^{-1}$ of fresh leaf) at different growth stages of rice as affected by dates of planting and nutrient management practices (Pooled data of 2 years)

\begin{tabular}{|c|c|c|c|c|c|c|c|c|c|}
\hline \multirow{2}{*}{ Treatments } & \multicolumn{3}{|c|}{ Chlorophyll a } & \multicolumn{3}{|c|}{ Chlorophyll b } & \multicolumn{3}{|c|}{ Total Chlorophyll } \\
\hline & 30 DAP & 60 DAP & 90 DAP & $30 \mathrm{DAP}$ & 60 DAP & $90 \mathrm{DAP}$ & $30 \mathrm{DAP}$ & $60 \mathrm{DAP}$ & $90 \mathrm{DAP}$ \\
\hline \multicolumn{10}{|l|}{ Date of Plantina } \\
\hline $10^{\text {th }}$ july & 2.29 & 2.36 & 1.20 & 1.02 & 1.26 & 0.69 & 3.07 & 3.62 & 1.89 \\
\hline $25^{\text {th }}$ july & 2.21 & 2.29 & 1.15 & 0.95 & 1.20 & 0.67 & 3.11 & 3.48 & 1.82 \\
\hline $\mathrm{SEm} \pm$ & 0.05 & 0.08 & 0.02 & 0.06 & 0.04 & 0.01 & 0.09 & 0.05 & 0.03 \\
\hline $\mathrm{CD}(\mathrm{P}=0.05)$ & N.S. & N.S. & N.S. & N.S. & N.S. & N.S. & N.S. & N.S. & N.S. \\
\hline \multicolumn{10}{|c|}{ Nutrient Management practices } \\
\hline STBFR & 2.07 & 1.99 & 1.00 & 0.76 & 1.08 & 0.61 & 2.67 & 3.07 & 1.61 \\
\hline STBFR+ GM & 2.46 & 2.55 & 1.29 & 1.14 & 1.38 & 0.74 & 3.61 & 3.93 & 2.04 \\
\hline STBFR+ FYM & 2.20 & 2.43 & 1.23 & 1.05 & 1.23 & 0.69 & 2.98 & 3.66 & 1.92 \\
\hline SEm \pm & 0.07 & 0.08 & 0.02 & 0.04 & 0.03 & 0.01 & 0.07 & 0.09 & 0.02 \\
\hline $\mathrm{CD}(\mathrm{P}=0.05)$ & 0.20 & 0.25 & 0.06 & 0.12 & 0.10 & 0.03 & 0.20 & 0.25 & 0.07 \\
\hline
\end{tabular}

Nutrient management had significant effect in improving chlorophyll content of rice. It was observed that chlorophyll a content was higher than chlorophyll $b$ at all the stages of rice. Chlorophyll a $\left(2.55 \mathrm{mg} \mathrm{g}^{-1}\right)$, Chlorophyll b $(1.38$ $\left.\mathrm{mg} \mathrm{g}^{-1}\right)$ as well as total chlorophyll (3.93 $\left.\mathrm{mg} \mathrm{g}^{-1}\right)$ were found to be significantly higher in STBFR+GM treated plot against STBFR alone $\left(1.99,1.08,3.07 \mathrm{mg} \mathrm{g}^{-1}\right)$ and statistically at par with STBFR+FYM treatment. Chlorophyll content increased progressively upto $60 \mathrm{DAP}$, thereafter decreased till harvest. Application of STBFR + GM improved nitrogen uptake that increased the chlorophyll content and leaf surface area resulting in increased photosynthesis and more sugar formation. Thus the increase in growth and yield owing to the application of fertilizers along with GM/FYM might be attributed to the fact that these nutrients $(N, P, K)$ being important constituents of nucleotides, proteins, chlorophyll 
and enzymes, involve in various metabolic processes which had direct impact on vegetative and reproductive phases of plants. These results are in agreement with those obtained by Pramanik and Bera (2013).

SPAD value did not differ significantly under different dates of planting. Higher SPAD values were observed at 60 DAP (46.87 and 44.05) in rice with nutrient management practice STBFR+GM and STBFR+FYM, respectively over STBFR alone (40.89). The SPAD readings indicated chlorophyll content and higher chlorophyll content was the indication of higher photosynthetic efficiency of plants. Uptake of higher levels of nitrogen in case of STBFR+GM (Table 2) increased the chlorophyll content resulting in higher photosynthetic capacity which may lead to higher yields. These results were in conformity with the findings of Mahajan et al., (2011) and Suresh et al., (2015). Similar results like Chlorophyll content were observed in case of SPAD value of the crop. As the SPAD value gave the best indication of photosynthetic activity in rice the increased chlorophyll content is correlated with increased rice yield.

Table 2: SPAD value, leaf $\mathrm{N}$ content (\%), grain and straw yield of rice crop as affected by dates of planting and nutrient management practices. (Pooled data of 2 years)

\begin{tabular}{c|cccc|c|c|c|c|c|}
\hline \multirow{2}{*}{ Treatments } & \multicolumn{3}{c|}{ SPAD value } & \multicolumn{3}{c|}{ Leaf N content (\%) } & Grain Yield \\
& 30 DAP & 60 DAP & 90 DAP & 30 DAP & 60 DAP & 90 DAP & $\begin{array}{c}\text { Straw yield } \\
\left(\mathrm{kg} \mathrm{ha}^{-1}\right)\end{array}$ \\
\hline Date of Planting \\
$10^{\text {th }}$ july & 33.20 & 44.73 & 31.80 & 2.39 & 2.90 & 2.58 & 5008 & 6151 \\
$25^{\text {th }}$ july & 31.83 & 43.15 & 30.94 & 2.33 & 2.79 & 2.51 & 4481 & 5630 \\
$\quad$ SEm \pm & 0.63 & 0.49 & 0.37 & 0.02 & 0.03 & 0.03 & 43.4 & 41.6 \\
CD $(P=0.05)$ & N.S. & N.S. & N.S. & N.S. & N.S. & N.S. & 150.3 & 144.0 \\
Nutrient Management practices & & & & & & & \\
STBFR & 30.73 & 40.89 & 29.95 & 2.13 & 2.65 & 2.39 & 4424 & 5505.4 \\
STBFR+ GM & 34.42 & 46.87 & 32.96 & 2.49 & 3.06 & 2.74 & 5015 & 6157 \\
STBFR+ FYM & 32.39 & 44.05 & 31.20 & 2.45 & 2.82 & 2.51 & 4794 & 6010 \\
$\quad$ SEm \pm & 0.63 & 0.97 & 0.51 & 0.03 & 0.03 & 0.03 & 54.5 & 71.9 \\
CD $(P=0.05)$ & 1.83 & 2.84 & 1.50 & 0.09 & 0.09 & 0.09 & 158.9 & 209.9 \\
\hline
\end{tabular}

Leaf $\mathrm{N}$ concentration was found to be numerically higher in all the stages of crop growth in earlier planting dates over 15 days delayed conditions. The pooled data showed that maximum $\mathrm{N}$ concentration in leaf $(2.90 \%)$ was found at $60 \mathrm{DAP}$, thereafter $\mathrm{N}$ concentration decreased (Table 2). Leaf nitrogen concentration was found to be significantly higher in STBFR + GM/FYM against STBFR alone. Highest nitrogen concentration in leaf were found in STBFR + GM $(2.49,3.06,2.74 \%)$ treated plot at all the stages, while the both combined treatment i.e STBFR + GM/FYM was found to be statistically at par in $\mathrm{N}$ concentration of leaf at initial stage (30 DAP). This might be due to organic manures which increased the adsorptive power of soil for cation and anion. These adsorbed ions were released slowly for entire crop growth period as crop absorbed them (Gadad et al., 2018, Suresh et al., (2015) led to higher $\mathrm{N}$ content of Leaf.

Earlier planting showed higher grain yield of $5008 \mathrm{~kg} \mathrm{ha}^{-1}$ and straw yield of $6151 \mathrm{~kg} \mathrm{ha}^{-1}$ than 15 days delay in planting. The yield decrease in late planting might have been due to an increase in the duration of the vegetative phase to the detriment of the reproductive and grain-filling phases as reported by Hussain et al. (2009), Lampayan et al. (2015). Higher grain and straw yield were observed in STBFR + GM $\left(5015,6157 \mathrm{~kg} \mathrm{ha}^{-1}\right)$ followed by STBFR+FYM and STBFR alone. This might be due to increased availability of plant nutrients from soil with addition of organic manure with inorganic fertilizers which maintained favourable physical, chemical and biological environment which ultimately reflected in increasing the yield parameters and yield. Similar findings were also reported by Bora et al. (2014), Tomar et al. (2018).

The result showed that SPAD value was linearly correlated with $\mathrm{N}$ content of leaves. Interaction of leaf $\mathrm{N}$ content and SPAD value of the crop indicated a strong, significant and positive relationship between them as the $R^{2}$ value range from 0.70-0.99 (Fig 1a, b \&c). At 90 days there was the strongest relation between 

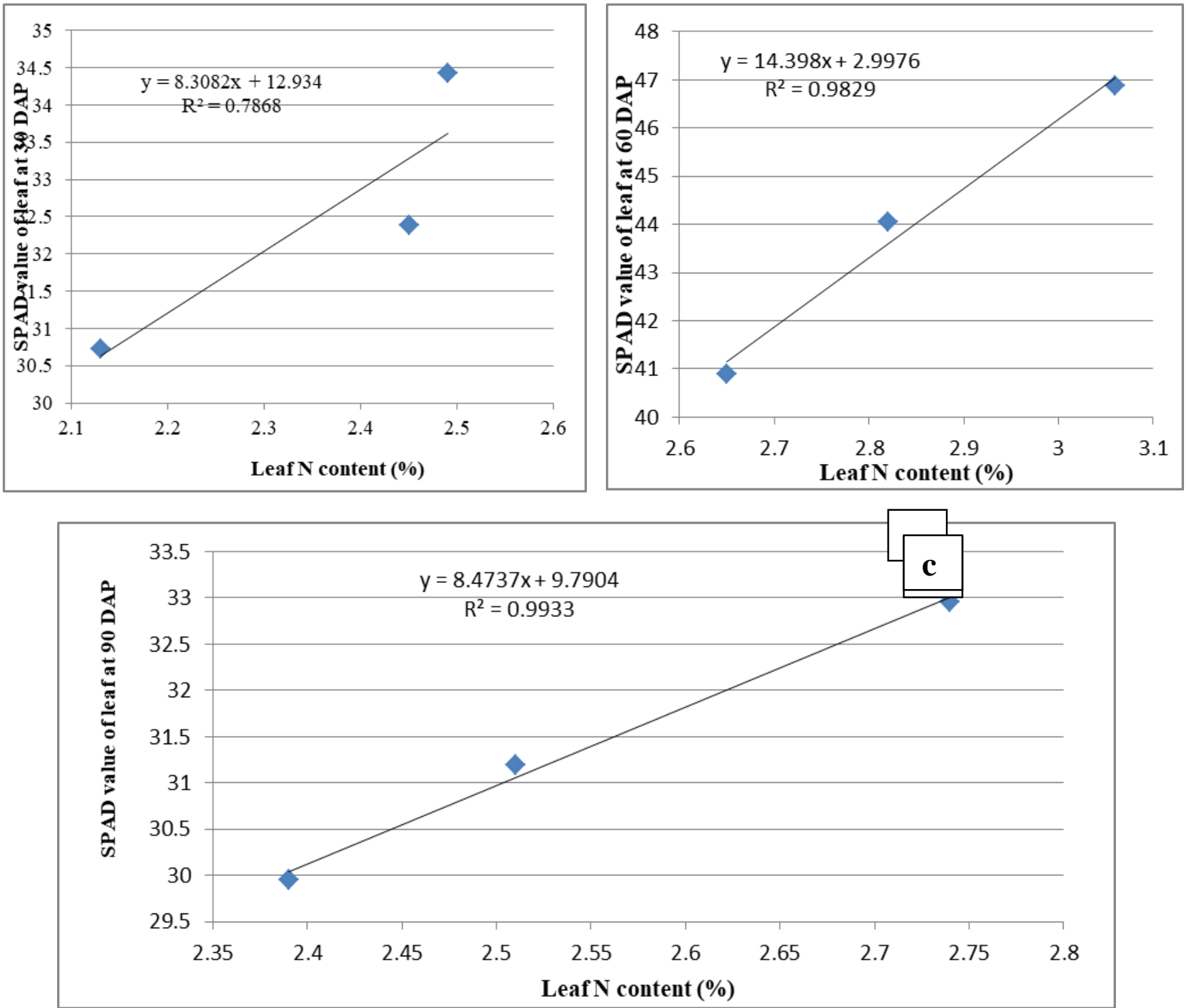

Figure 1: Interactions among Leaf $\mathrm{N}$ content and SPAD values of rice

leaf $\mathrm{N}$ content and SPAD value recorded (Fig 1c). Islam et al., (2009) reported strong relationship between SPAD values and leaf $\mathrm{N}$ concentration, but this relationship varied with crop growth stage, this variation mostly because of leaf thickness or specific leaf weight. However, the relationship between leaf $\mathrm{N}$ content and SPAD value indicated that when a treatment showed higher SPAD value, it had certainly higher amount of nitrogen. This correlation between SPAD and Leaf nitrogen concentration was observed by Giletto and Echeverría, (2013), Errecart et al., (2012). This SPAD values helped in predicting $N$ status of the crop instantaneously for correction of the $\mathrm{N}$ deficiency, if any. This linear relationship and high SPAD value, leaf $\mathrm{N}$ content at STBFR+GM indicated that the crop responded well to the treatment. The observed linear relationship between leaf $\mathrm{N}$ content and SPAD values had led to determine the plants need to assess crop $\mathrm{N}$ status and to determine the need for additional $\mathrm{N}$ fertilizer (Huang et al., 2008, Swain and Jagtap sandip, 2010, Yoseftabar et al., 2012).

From the present study, it may be concluded that 15 days early planting increased leaf N, Chlorophyll a, Chlorophyll b, total Chlorophyll content as well as SPAD value of rice. Among nutrient management practices, crop grown with STBFR+GM resulted better growth, higher leaf $\mathrm{N}$ and chlorophyll content as well as SPAD value of the rice crop which ultimately improved yield. 


\section{REFERENCES}

Bora, I.P., Baruah, A. and Singh, J. (2008) Integrated use of legume green manure and inorganic fertilizer on soil health, nutrient uptake and productivity of rice (oryza sativa l.) in shifting cultivation of Assam. Indian Journal Agricultural Research 42(4): 260-265.

Errecart, P.M., Agnusdei, M.G., Lattanzi, F.A., and Marino, M.A. (2012) Leaf nitrogen concentration and chlorophyll meter readings as predictors of tall fescue nitrogen nutrition status. Field Crops Research. 129: 46-58.

Gadad, S.K., Gogoi, P.K. and Konwar, M.J. (2018) Growth parameters of autumn rice under various irrigation schedules and nutrient management. Indian Journal of Agricultural Research 52(2): 207-210.

Giletto, C.M., and Echeverría, H.E. (2013) Chlorophyll meter for the evaluation of potato $\mathrm{N}$ status. American Journal of Potato Research. 90:313-323

Gomez, K.A. and Gomez, A.A. (1984). Statistical procedures for agricultural research. A Willey Inter Science Publication, New York, pp.76-83.

Huang, J. F.He, Roland, K Ci, J., Buresh, B.X., Gong, W. and Peng, S. (2008) Determination of optimal nitrogen rate for rice varieties using a chlorophyll meter. Field Crops Research. 105:70-80

Hussain, A., Bhat, M.A., Ganai, M.A. and Hussain, T. (2009) Influence of planting dates and spacing schedules on performance of basmati rice Pusa Sugandh-3 under Kashmir valley condition. Environment and Ecology. 27(1A): 396-398.

Islam, M.S.H , Bhuiya, M.S.U., Rahman, S. and Hussain, M . (2009) Evaluation of SPAD and LCC based nitrogen management in rice (Oryza sativa L.). Bangaladesh Journal of Agricultural Research. 34(4):661-672.
Lampayana,, R.M., Faroniloa, J.E., Tuonga, T.P., Espiritub, A.J., De Diosb, J.L., Bayota, R.S., Buenoa, C.S. and Hosena, Y. (2015) Effects of seedbed management and delayed transplanting of rice seedlings on crop performance, grain yield, and water productivity. Field Crops Research 183:303-314.

Mahajan G., Chauhan B. S. and Gill M. S. (2011) Optimal nitrogen fertilization timing and rate in dry-seeded rice in northwest India. Agronomy Journal 103(6): 1676-1682.

Nayek, S., Choudhury, I.H., Jaishee, N. and Roy, S. (2014) Spectrophotometric analysis of chlorophylls and carotenoids from commonly grown fern species by using various extracting solvents. Research Journal of Chemical Sciences 4(9):63-69.

Pramanik, K. and Bera, A.K. (2013) Effect of seedling age and nitrogen fertilizer on growth, chlorophyll content, yield and economics of hybrid rice (Oryza sativa L.) International Journal of Agronomy and Plant Production 4 (S): 3489-3499

Swain, D.K. and Jagtap, S.S., (2010) Development of SPAD values of medium and long duration rice variety for site specific nitrogen management. Journal of Agronomy 9(2):38-44

Tomar, R., Singh, N.B., Singh, V. and Kumar, D. (2018) Effect of planting methods and integrated nutrient management on growth parameters, yield and economics of rice. Journal of Pharmacognosy and Phytochemistry 7(2): 520-527.

Yoseftabar, S., Fallah, A.and Daneshian, J. (2012) Effect of split application of nitrogen fertilizer on SPAD values in hybrid rice (Grh1). International Journal of Agriculture and Crop Sciences 4-10: 647-651. 